\title{
Complete hydatidiform mole in a twin complicated with preeclampsia: a case report
}

\author{
Feyza Nur İncesu Çintesun', Ersin Çintesun², Ayşe Yavuz ${ }^{3}$ \\ ${ }^{1}$ Gynecology and Obstetrics Clinic, Konya Training and Research Hospital, Konya, Turkey \\ ${ }^{2}$ Department of Obstetrics and Gynecology, Faculty of Medicine, Selçuk University, Konya, Turkey \\ ${ }^{3}$ Department of Pathology, Konya Training and Research Hospital, Konya, Turkey
}

\begin{abstract}
Objective: Molar pregnancy is the part of a disease group classified as gestational trophoblastic disease which originates from the placenta and has the potential to invade uterus locally and to develop metastasis. The chance for the presence of twin fetus together with molar pregnancy is very rare. Also, the conditions such as hyperthyroidism and preeclampsia could be seen in earlier weeks and more frequently during molar pregnancy. In our case, we aimed to present the case of a complete molar pregnancy which developed preeclampsia and ablatio placentae and accompanied by 18 -week-old dead fetus.

Case: Twenty-five years old and multigravida case was established with the diagnosis of 18-week-old intrauterine fetus. According to the laboratory examinations and clinical findings, the diagnoses of molar pregnancy, preeclampsia and ablatio placentae were established for one of the twins. Magnesium sulfate treatment was initiated for labor induction and the pregnancy was terminated. The twin was reported as complete mole by the histopathological examination of the specimen. No complication developed in the follow-ups of the patient.

Conclusion: The pregnancies with molar twin are the cases which should be paid attention in terms of medical complications such as preeclampsia, thyrotoxicosis and gestational trophoblastic neoplasia.
\end{abstract}

Keywords: Complete mole, preeclampsia, twin pregnancy.

\section{Introduction}

Molar pregnancy (hydatidiform mole or mole) is the part of a disease group classified as gestational trophoblastic disease which originates from the placenta and has the potential to invade uterus locally and to develop metastasis. Although molar pregnancies are usually of benign
Özet: Preeklampsi ile komplike olmuş ikiz eşi komplet mol hidatidiform: Olgu sunumu

Amaç: Molar gebelik, plasentadan köken alan ve lokal olarak uterusu istila etme ve metastaz yapma potansiyeline sahip gestasyonel trofoblastik hastalık olarak sınıflandırılan hastalık grubunun bir parçasıdır. Molar gebelik ile birlikte ikiz eşi fetüsün bulunma olasılığı oldukça nadirdir. Ayrıca molar gebelikte hipertiroidi, preeklampsi gibi durumlar da daha erken haftalarda ve daha sık görülebilmektedir. Bu olgumuzda preeklampsi ve plasenta dekolman gelişen 18 hafta ex fetüsün eşlik ettiği komplet molar gebelik olgusunun sunulması amaçlanmıştır.

Olgu: Yirmi beş yaşında, multigravida, son adet tarihine göre 18 hafta intrauterin fetüs tanısı konuldu. Laboratuvar tetkileri ve klinik bulguları sonucuna göre ikiz eşi molar gebelik, preeklampsi ve plasental dekolman tanısı konuldu. Hastaya magnezyum sülfat tedavisi başlanarak doğum indüksiyonu yapıldı ve gebelik sonlandırıldı. Alınan piyesin histopatolojik incelemesinde ikiz eşi komplet mol olarak rapor edildi. Hastanın takiplerinde herhangi bir komplikasyon gelişmedi.

Sonuç: İkiz eşi molar gebelikler erken başlangıçlı preeklampsi, tirotoksikoz ve gestasyonel trofoblastik neoplazi gibi tıbbi komplikasyonlar yönüyle dikkat edilmesi gereken gebeliklerdir.

Anahtar sözcükler: İkiz gebelik, komplet mol, preeklampsi.

characteristics, they are considered as a premalignant disease due to their malignancy potential. They have two sub-groups which are complete and partial, and these two groups vary according to their macroscopic and microscopic appearance, and karyotype and malignancy potentials. ${ }^{[1]}$ In the literature, molar pregnancy incident varies
Correspondence: Ersin Çintesun, MD. Department of Gynecology and Obstetrics, Faculty of Medicine, Selçuk University, Konya, Turkey. e-mail: ersincintesun@gmail.com Received: October 12, 2017; Accepted: December 5, 2017

Please cite this article as: İncesu Çintesun FN, Çintesun E, Yavuz A. Complete hydatidiform mole in a twin complicated with preeclampsia: a case report. Perinatal Journal 2017;25(3):145-148.

(C2017 Perinatal Medicine Foundation
Available online at: www.perinataljournal.com/20170253007 doi: $10.2399 /$ prn.17.0253007 QR (Quick Response) Code:

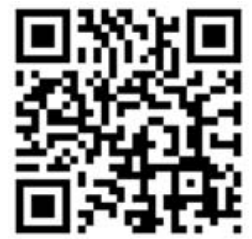


among regions; while it is 66-121/100,000 in North America and Europe, it is 23-1299/100,000 in Latin America, Asia and Middle East. ${ }^{[2]}$ In the UK, one complete mole was reported per 1000 pregnancies and three partial mole cases were reported per 1000 pregnancies. ${ }^{[3]}$ Presence of twin fetus in complete molar pregnancy is very rare and its incidence varies between $1 / 10,000$ and $1 / 100,000 .^{[4]}$ Also, the complications such as hyperthyroidism and preeclampsia could be seen in earlier weeks and more frequently during complete molar pregnancy. ${ }^{[3]}$ In our case, we aimed to present a patient with complete molar pregnancy which was complicated with preeclampsia and accompanied by 18 -week-old dead fetus.

\section{Case Report}

Twenty-five-year-old patient who was multigravida and at 18 weeks of gestation according to her last menstrual period applied to our clinic with high blood pressure

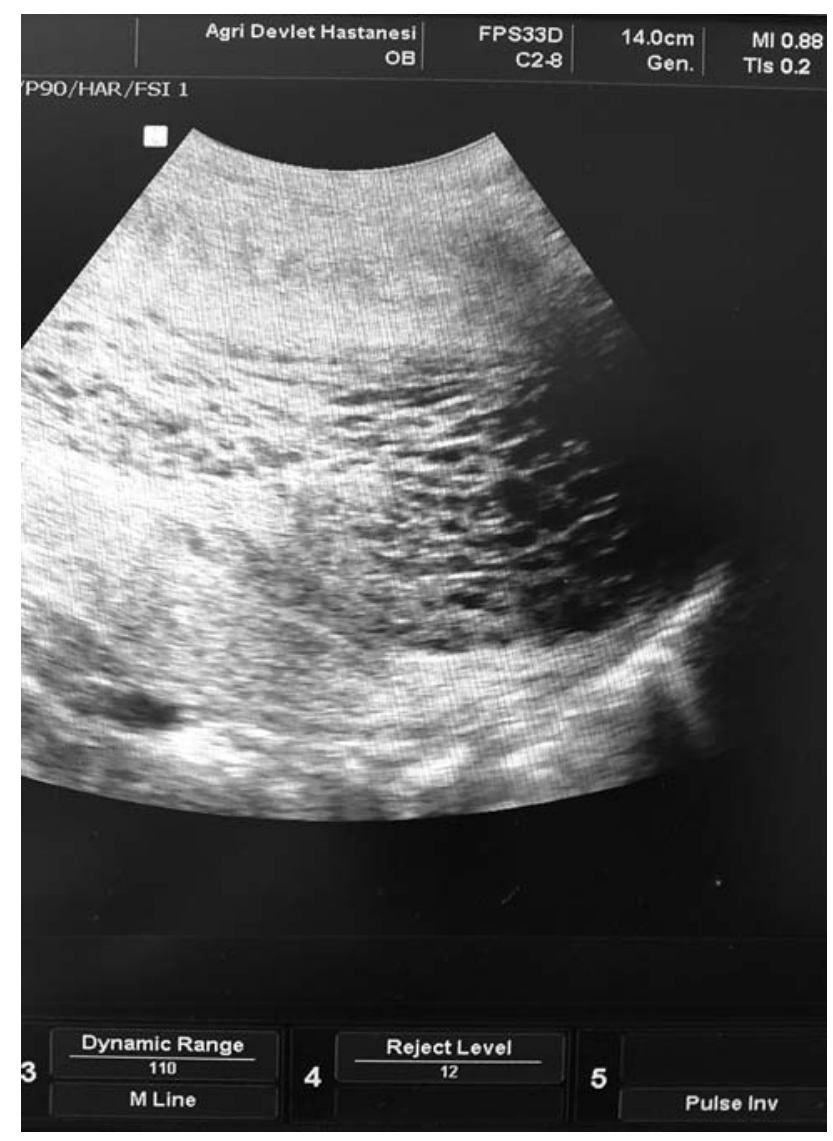

Fig. 1. The ultrasonographic image of placenta.
$(180 / 120 \mathrm{mmHg})$ and vaginal bleeding complaints. We learnt from her medical history that she did not undergo any regular antenatal follow-up, underwent antenatal follow-up only once throughout her pregnancy and no ultrasonographic examination was performed. In the fetal ultrasonography, we observed that there was one fetus, which had no fetal heart beat and was consistent with 18 weeks of gestation, and also a suspicious detachment area approximately $12 \mathrm{~cm}$ within the placenta having a multicystic heterogeneous appearance in the placenta (Fig. 1). During the admission, the patient was conscious and had no headache, blurred vision and severe epigastric pain. In the pelvic examination, $3 \mathrm{~cm}$ cervical dilatation, active vaginal bleeding and fetal structures protruded from the cervix were seen. In the laboratory examination, hemoglobin $(\mathrm{Hb})$ was $9.37 \mathrm{~g} / \mathrm{d}, \beta$-hCG was $185,210 \mathrm{mIU} / \mathrm{mL}$, dipstick test had +2 proteinuria, and other parameters were normal. Two units of erythrocyte suspension were prepared for the patient whose blood type was $\mathrm{A}(\mathrm{Rh}+)$. The pre-diagnosis of the patient was twin pregnancy accompanied by complete molar pregnancy or preeclampsia and ablatio placentae complicated by partial molar pregnancy. As antihypertensive agent, alphamethyldopa $20 \mathrm{mg} 3 \times 1$ was administered to the patient. For eclampsia prophylaxis, $6 \mathrm{~g}$ magnesium sulfate was administered in 15-20 minutes as loading dose followed by $1.5 \mathrm{~g}$ maintenance dose per hour. Low dose intravenous oxytocin $(10 \mathrm{mU} / \mathrm{mL}$ oxytocin in isotonic solution) was administered for abortion, and the patient aborted dead male fetus in a short time. Since the bleeding did not stop after abortion and the placenta did not detach completely, endometrial cavity was emptied entirely by vacuum curettage under ultrasonography and general anesthesia. The placenta was examined after the procedure and it was seen that $30 \%$ of it was the detachment area and there were many vacuoles (Fig. 2). Since

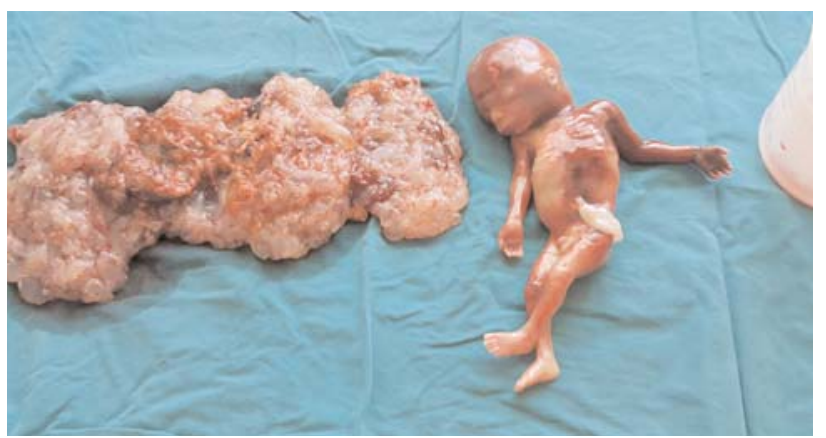

Fig. 2. The macroscopic images of placenta and fetus. 
postoperative $\mathrm{Hb}$ level was $6.4 \mathrm{~g} / \mathrm{dl}$, transfusion was carried out with 2 units of erythrocyte suspension. The patient was discharged 4 days later as her postoperative clinical follow-ups were stable. Pathological examination reported dead fetus consistent with 18 weeks of gestation and complete hydatidiform mole (Fig. 3). In her followups, no lesion was observed in the chest radiography and $\beta$-hCG values were completely within normal reference ranges.

\section{Discussion}

Presence of complete mole together with live fetus is reported between $1 / 10,000$ and 1/100,000 in the literature. ${ }^{[4]}$ There are three possibilities when molar pregnancy is observed together with the fetus: (1) First fetus being normal and second fetus being complete molar pregnancy, (2) presence of triploid fetus in partial molar pregnancy, and (3) presence of normal fetus in partial molar pregnancy. ${ }^{[4]}$ Getting pregnant at an advanced age as a result of ovulation induction is a risk factor for this condition. ${ }^{[5]}$ The diagnosis of multiple pregnancies accompanied by molar pregnancy can be established with the help of ultrasonography; however, invasive genetic examinations such as amniocentesis and cordocentesis are required for a definite diagnosis. Such patients should be informed in detail about the potential risks. Presence of complications such as preeclampsia, hemorrhage or thyrotoxicosis during second trimester, preterm labor and/or the risk for developing gestational trophoblastic neoplasia (GTN) are among these risks. ${ }^{[6]}$ Due to the lack of genetic laboratory in the center that our case admitted and clinical emergency, we could not carry out genetic examination on fresh specimen during abortion. The genetic examination carried out via paraffin blocks following the procedure failed.
There is a potential risk that molar pregnancies may turn into GTN. The risk for complete molar pregnancies changing into GTN is higher than the partial molar pregnancies. The risk of developing GTN after complete molar pregnancies is $15-20 \%$ while it is $1-5 \%$ after partial moles. ${ }^{[7,8]}$ We followed up our case by chest radiography and serial $\beta$-hCG monitoring after her discharge, and did not observe any malignancies.

While the diagnosis of complete molar pregnancy had been established during second trimester, the improvements in the sensitivity of $\beta$-hCG measurement and ultrasonography becoming prevalent have made it possible to establish diagnosis even during the first trimester. In patients diagnosed during first trimester, preeclampsia, hyperemesis gravidarum and GTN associated with molar pregnancy are seen more rarely. ${ }^{[9-11]}$ Great and soft uterus according to the week of gestation, vaginal bleeding, early development of preeclampsia (before 20 weeks), hyperemesis gravidarum, theca lutein cyst and hyperthyroidism are seen in complete molar pregnancy. In some of the patients with complete molar pregnancy, development of malign gestational trophoblastic diseases is also observed. $\beta$-hCG secreted excessively in complete mole usually causes the development of these symptoms. ${ }^{[12]}$ In our case, we observed preeclampsia, ablatio placentae and death of twin at 18 weeks of gestation associated with the complete mole. We thought that ablatio placentae developed probably secondarily to the preeclampsia.

Molar pregnancies are sometimes seen in twin pregnancies. In twin pregnancies, complete or partial mole and accompanying live fetus can be seen; however, this is very rare. ${ }^{[4]}$ Getting pregnant at an advanced age as a result of ovulation induction is a risk factor for this con-
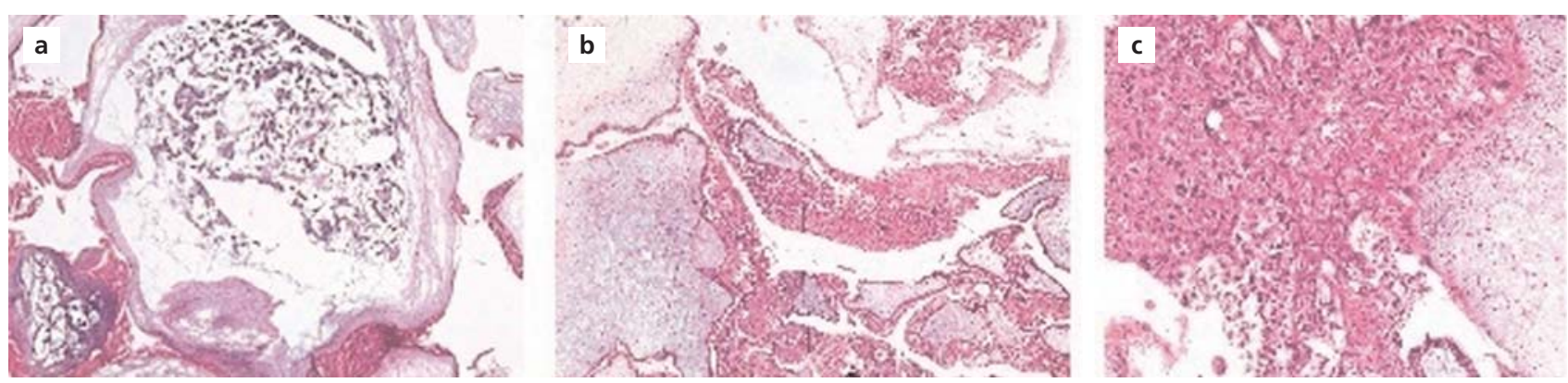

Fig. 3. Histopathological images. (a) Generalized stromal edema in villus (HE $\times 25)$. (b) Peripheral trophoblast spread from enlarged villus surface $(\mathrm{HE} \times 25)$. (c) Cytologic atypia and focal necrosis on complete mole trophoblast (HE $\times 50)$. 
dition. ${ }^{[5]}$ The diagnosis of multiple pregnancies accompanied by molar pregnancy can be established with the help of ultrasonography; however, invasive genetic examinations such as amniocentesis and cordocentesis are required for a definite diagnosis. Such patients should be informed in detail about the potential risks. Presence of complications such as preeclampsia, hemorrhage or thyrotoxicosis during second trimester, preterm labor and/or the risk for developing GTN are among these risks. ${ }^{[6]}$ The widest series on twin pregnancies accompanied by molar pregnancy was published by Charing Cross and Weston Park Gestational Trophoblastic Disease Centers in the UK. ${ }^{[13]}$ In this study, 51 patients who decided to continue the pregnancy out of 90 twin and complete molar pregnancy patients were followed up between 1998 and 2011. Twenty-nine (57\%) of these patients delivered live babies whose mean gestational age was 34 weeks, and 24 (26.7\%) of 90 patients developed GTN. ${ }^{[13]}$ When our case admitted to our center, her labor was induced immediately due to the vaginal bleeding and lack of fetal heart beat. Our case developed preeclampsia during the early weeks of gestation. We first suspected of molar pregnancy by the abortion material and the appearance of placenta; however, we could not distinguish complete mole accompanied by the twin pregnancy from partial mole with deteriorated placental development, and the definitive diagnosis could be established by pathology report.

\section{Conclusion}

The pregnancies with molar twin are the cases which should be paid attention in terms of medical complications such as preeclampsia, thyrotoxicosis and GTN. Although USG is used effectively for the diagnosis of molar pregnancy, it should be kept in mind that molar degeneration may not always be detected during the first trimester. The assessment of placenta is very important in the fetal ultrasonography. Also, in early-onset preeclampsia, thyrotoxicosis, vaginal bleeding dead fetus cases, complete mole and accompanying twin pregnancy should be considered in the differential diagnosis.

Conflicts of Interest: No conflicts declared.

\section{References}

1. Vassilakos P, Riotton G, Kajii T. Hydatidiform mole: two entities. A morphologic and cytogenetic study with some clinical consideration. Am J Obstet Gynecol 1977;127:167-70.

2. Altieri A, Franceschi S, Ferlay J, Smith J, La Vecchia C. Epidemiology and aetiology of gestational trophoblastic diseases. Lancet Oncol 2003;4:670-8.

3. Newlands ES, Paradinas FJ, Fisher RA. Recent advances in gestational trophoblastic disease. Hematol Oncol Clin North Am 1999; 13:225-44, x.

4. Ruffolo LEH. Hydatidiform mole and a seven-month fetus: report of a case. Obstet Gynecol 1956;8:296-8.

5. Shazly SA, Ali MK, Abdel Badee AY, Alsokkary AB, Khodary MM, Mostafa NA. Twin pregnancy with complete hydatidiform mole and coexisting fetus following ovulation induction with a non-prescribed clomiphene citrate regimen: a case report. J Med Case Rep 2012;6:95.

6. Vejerslev LO. Clinical management and diagnostic possibilities in hydatidiform mole with coexistent fetus. Obstet Gynecol Surv 1991;46:577-88.

7. Berkowitz RS, Goldstein DP. Current advances in the management of gestational trophoblastic disease. Gynecol Oncol 2013; 128:3-5.

8. Berkowitz RS, Goldstein DP. Chorionic tumors. N Engl J Med 1996;335:1740-8.

9. Sebire NJ. The diagnosis of gestational trophoblastic disease in early pregnancy: implications for screening, counseling and management. Ultrasound Obstet Gynecol 2005;25:421-4.

10. Hou JL, Wan XR, Xiang Y, Qi QW, Yang XY. Changes of clinical features in hydatidiform mole: analysis of 113 cases. J Reprod Med 2008;53:629-33.

11. Soto-Wright V, Bernstein M, Goldstein DP, Berkowitz RS. The changing clinical presentation of complete molar pregnancy. Obstet Gynecol 1995;86:775-9.

12. Schlaerth JB, Morrow CP, Montz FJ, d'Ablaing G. Initial management of hydatidiform mole. Am J Obstetr Gynecol 1988; 158:1299-306.

13. Niemann I, Fisher R, Sebire N, Wells M, Short D, Tidy J, et al. Update on UK outcomes for women with twin pregnancies comprising a complete hydatidiform mole (CHM) and normal co-twin. ISSTD World Congress XVII, Chicago, 2013. p. 57. 